\title{
Effects of hydrogen peroxide on mucociliary transport in human airway epithelial cells.
}

\section{$\operatorname{AUTHOR}(\mathrm{S}):$}

Honda, Akiko; Murayama, Rumiko; Matsuda, Yugo; Tsuji, Kenshi; Sawahara, Takahiro; Fukushima, Wataru; Hayashi, Tomohiro; Shimada, Akinori; Takano, Hirohisa

\section{CITATION:}

Honda, Akiko ... [et al]. Effects of hydrogen peroxide on mucociliary transport in human airway epithelial cells.. Toxicology mechanisms and methods 2014, 24(3): 191-195

\section{ISSUE DATE:}

2014-01-13

URL:

http://hdl.handle.net/2433/199890

\section{RIGHT:}

This is an Accepted Manuscript of an article published by Taylor \& Francis in "Toxicology Mechanisms and Methods" on Published online: 13 Jan 2014, available online: http://www.tandfonline.com/10.3109/15376516.2013.876136; This is not the published version. Please cite only the published version.; この論文は出版社版でありません。引用の際には出 版社版をご確認ご利用ください。 
Original Papers

Effects of hydrogen peroxide on mucociliary transport in human airway epithelial cells

Akiko Honda $^{\mathrm{a}}$, Rumiko Murayama ${ }^{\mathrm{a}}$, Yugo Matsuda ${ }^{\mathrm{a}}$, Kenshi Tsuji ${ }^{\mathrm{a}}$, Takahiro Sawahara ${ }^{\mathrm{a}}$,

Wataru Fukushima $^{\mathrm{a}}$, Tomohiro Hayashi ${ }^{\mathrm{a}}$, Akinori Shimada ${ }^{\mathrm{b}}$, and Hirohisa Takano ${ }^{\mathrm{a}}$

${ }^{a}$ Environmental Health Division, Department of Environmental Engineering, Graduate School

of Engineering, Kyoto University. C Cluster, Kyoto-Daigaku-Katsura, Nishikyo-ku, Kyoto 6158540, Japan.

${ }^{b}$ Laboratory of Environmental Pathology School of Life and Environmental Science Azabu

University, 1-17-71 Fuchinobe, Cyuo-ku, Sagamihara, Kanagawa, 252-5201, Japan.

Running title : $\mathrm{H}_{2} \mathrm{O}_{2}$ affects mucociliary transport in airway

Corresponding author: Dr. Akiko Honda

Phone: +81 75383 3345; Fax: +81 753833344

Email: akko@health.env.kyoto-u.ac.jp

Keywords: airway epithelial cells, air-liquid interface culture, mucociliary transport, hydrogen peroxide 


\section{Abstract}

The effects of environmental pollutants on airway clearance have not been well elucidated. This study examined mucociliary transport using different sized-fluorescent particles on polarized human airway epithelial cells which were maintained in an air-liquid interface (ALI) culture system. The effects of hydrogen peroxide $\left(\mathrm{H}_{2} \mathrm{O}_{2}\right)$ exposure on mucociliary transport were also investigated. The movement of fluorescent particles with diameters of $10-14 \mu \mathrm{m}$ and $2.5-4.5 \mu \mathrm{m}$ was observed by fluorescent microscopy as an index of the mucociliary transport. The mixture of the particles with two different sizes were propelled concentrically on the apical surface by the interaction of ciliary activity and mucus in the control condition, whereas $\mathrm{H}_{2} \mathrm{O}_{2}$ exposure for 24 h significantly inhibited the movement of the particles. The particle sizes did not affect their movement after the control or $\mathrm{H}_{2} \mathrm{O}_{2}$ exposure. These results suggest that particle tracking on polarized human airway epithelial cells is a useful experimental tool for the evaluation of the effect of environmental pollutants on mucociliary transport. In addition, reactive oxygen species may impair mucociliary transport, leading to the airway damage, and exacerbation of respiratory diseases. 


\section{Introduction}

Airway epithelial cells are composed of a variety of cell types, including ciliated, goblet, and basal cells, and they function as the first barrier against inhaled xenobiotics (Tam et al. 2011). Goblet cells, in particular, synthesize and secrete mucin-rich mucus which traps the inhaled particles, viruses and bacteria, and then these xenobiotics are eliminated from the respiratory tract by mucociliary transport. The airway's surface liquid consists of two types of liquid where the upper layer is highly viscous and the lower is watery. The cilia are immersed in the watery layer with lower viscosity, which enables the cilia to beat (Smith et al. 2008; Cone et al. 2009). The overlying mucous layer is propelled by the penetration of cilia tips during beating.

In previous studies, airway epithelial cell lines such as A549, BEAS-2B and Calu3 have contributed to respiratory research. Polarized human airway epithelial cells have also been used as a respiratory model; they enable mucociliary transport (Bayam et al. 1998). Air-liquid interface (ALI) cultures are under development as a useful tool for analyses of airway epithelial cell function. For example, in an ALI culture, basal-lateral side of epithelial cells is immerged in culture medium and the apical side is exposed to humidified air with $5 \% \mathrm{CO}_{2}$. Not only the monolayer but also polarized epithelial cells have been introduced to ALI cultures (Seagrave et al. 2007; Huang et al. 2009; Stewart et al. 2012). These cultures mimic the construction of the airway and enable us to conduct in vitro studies under conditions that are close to in vivo 
conditions. Accordingly, ALI cultures are one of the airway models that make evaluations of advanced function easier.

The impairment of mucociliary transport by environmental pollutants may cause or increase the risk of respiratory diseases such as asthma. Hydrogen peroxide $\left(\mathrm{H}_{2} \mathrm{O}_{2}\right)$ is one of the major reactive oxygen species (ROS) known to induce oxidative stress, which leads subsequently to cellular damage in the airway. $\mathrm{H}_{2} \mathrm{O}_{2}$ is synthesized by exogenous or endogenous sources. In exogenous sources, $\mathrm{H}_{2} \mathrm{O}_{2}$ is produced through the bimolecular combination of $\mathrm{HO}_{2}$, which is produced primarily from the photolysis of $\mathrm{O}_{3}\left[\mathrm{HO}_{2}+\mathrm{HO}_{2}\left(+\mathrm{H}_{2} \mathrm{O}\right)\right.$ $\rightarrow \mathrm{H}_{2} \mathrm{O}_{2}+\mathrm{O}_{2}$ ] (Lee et al. 2000). Exogenous $\mathrm{H}_{2} \mathrm{O}_{2}$ stimulates cell surface molecules or is diffusible through cell membranes. Previous studies have suggested that $\mathrm{H}_{2} \mathrm{O}_{2}$ causes mucin synthesis via transactivation of epidermal growth factor receptor in mucoepidermoid carcinoma cells from human lungs (NCI-H292), and that $\mathrm{H}_{2} \mathrm{O}_{2}$ affects tracheobronchial mucosa in guinea pigs (Greiff et al. 1999; Takeyama et al. 2000). In addition, McDonald et al (1993) have demonstrated that exogenous $\mathrm{H}_{2} \mathrm{O}_{2}$ exposure induces DNA single-strand breaks in airway epithelial cells. In endogenous sources, $\mathrm{H}_{2} \mathrm{O}_{2}$ is produced from mitochondria as the site of energy generation, and is converted to the hydroxyl radical which is highly reactive and induces cell damage (Ryter et al. 2007). A large number of studies have suggested that environmental pollutants including diesel exhaust particles, polycyclic aromatic hydrocarbons, metal and sand dust induce oxidative stress in the airway (Dye et al. 1999; Marano et al. 2002; Kim et al. 2003; 
Chiba et al. 2011). However, the effects of oxidative stress and/or environmental pollutants on airway clearance have not been established.

The aim of the present study was to investigate whether commercially available polarized human airway epithelial cells are useful for the analysis of mucociliary transport and for evaluation of the effects of oxidative stress and/or environmental pollutants on mucociliary transport. Accordingly, we measured the movement of fluorescent particles on human airway epithelial cells maintained in an ALI culture system as an index of mucociliary transport.

\section{Materials and methods}

\subsection{Air-liquid interface (ALI) cultures}

Human airway epithelial cells, differentiated in a polarized primary culture (MucilAir ${ }^{\mathrm{TM}}$, Epithelix Sarl, Geneva, Switzerland), were derived from bronchial biopsies of a healthy male donor (Caucasian) and were cultivated on micro-porous filter in cell culture inserts. They were provided by Iwaki, Ltd. (Tokyo, Japan) and maintained in an ALI culture system according to the manufacturer's instructions using MucilAir ${ }^{\mathrm{TM}}$ culture medium at $37^{\circ} \mathrm{C}$ in a humidified atmosphere of $5 \% \mathrm{CO}_{2}$. After cells were maintained for about 5 months, we used them for experiments. 
To confirm the differentiation of human airway epithelial cells, the cells were fixed in $10 \%$ formalin and embedded in paraffin wax. Sections were cut at $5 \mu \mathrm{m}$ and stained with haematoxylin and eosin (HE) or periodic acid-Schiff (PAS).

\subsection{Experimental protocol}

Each insert was added apically with $200 \mu \mathrm{L}$ saline solution $(0.9 \% \mathrm{NaCl}, 1.25 \mathrm{mM}$ $\mathrm{CaCl}_{2}, 10 \mathrm{mM}$ HEPES) for $30 \mathrm{~min}$ in a $\mathrm{CO}_{2}$ incubator $24 \mathrm{~h}$ prior to the experiments. This washing step allowed the removal of accumulated mucus and therefore minimized the risk of interference with the test. The following day, the cells were incubated for 1 min in $200 \mu \mathrm{L}$ of saline solution ( $0.9 \% \mathrm{NaCl}, 1.25 \mathrm{mM} \mathrm{CaCl}_{2}, 10 \mathrm{mM}$ HEPES) as control or $500 \mu \mathrm{M} \mathrm{H}_{2} \mathrm{O}_{2}$ (diluted in saline solution) and, all of the apical surface were exposed by saline solution or $\mathrm{H}_{2} \mathrm{O}_{2}$. However, it has been reported that applying an excess volume of $0.9 \% \mathrm{NaCl}$ for a long time on the apical surface of MucilAir ${ }^{\mathrm{TM}}$ results in increased interleukin (IL)-8 release (Huang and Caulfuty 2009), then the saline solution or $\mathrm{H}_{2} \mathrm{O}_{2}$ was removed to avoid IL-8 release. A mixture of particles with two different sizes was prepared by polystyrene particles with diameters of $10-14 \mu \mathrm{m}$ and 2.5-4.5 $\mu \mathrm{m}$ at each concentration of $1000 \mu \mathrm{g} / \mathrm{mL}$ (Spherotech, Lake Forest, IL, USA). Twenty $\mu \mathrm{L}$ (no toxic volume) of saline solution or $\mathrm{H}_{2} \mathrm{O}_{2}$ including fluorescent particles was applied at the apical surface. The inserts were incubated in a $\mathrm{CO}_{2}$ incubator for $24 \mathrm{~h}$, and the mucociliary transport was then evaluated by video-microscopy. 


\subsection{Video-microscopy analysis of mucociliary transport}

The motion and migration rate of polystyrene particles with diameters of $10-14 \mu \mathrm{m}$ and 2.5-4.5 $\mu \mathrm{m}$ were used as an index of mucociliary transport. The movement of the mixed particles was observed with a fluorescence microscope (Keyence, Osaka, Japan) equipped with $200 \times$ or $40 \times$ magnification. The data were recorded at two opposite points (areas 1 and 2) per individual culture insert for $20 \mathrm{sec}$ (Fig. 1). The movement of particles with each diameter was expressed as the percentage of migration compared to that of particles with a diameter of 10 $14 \mu \mathrm{m}$ under control condition at area 1 using Image_Pro_Plus software (Media Cybernetics, Rockville, MD, USA). The migration rate was filtered by excluding data on the particles which were not recognized as reliable particles because of the short detection time.

\section{Results}

\subsection{Morphological features of airway epithelial cells in ALI culture system}

We confirmed the morphology of airway epithelial cells in ALI cultures. Fully differentiated epithelial cells including ciliated, goblet and basal cells were observed by HE staining (Fig. 2A). Goblet cells and mucus were identified more on the apical side than on the basal side by PAS staining (Fig. 2B). 


\subsection{Effects of $\mathrm{H}_{2} \mathrm{O}_{2}$ on mucociliary transport of airway epithelial cells in ALI culture system}

When there were no fluorescent particles on the apical side of the airway epithelial cells, the beating of the cilia was observed as a flickering appearance, because of the frequency of the beating. The movement of cellular debris was seen to be in circles under $200 \times$ magnification (Movie 1). After removing the cellular debris by washing, we investigated the effect of $\mathrm{H}_{2} \mathrm{O}_{2}$ on the mucociliary transport of airway epithelial cells $24 \mathrm{~h}$ after the exposure. We obtained two opposite points per individual culture insert to evaluate the response to $\mathrm{H}_{2} \mathrm{O}_{2}$ exposure. The particles with a diameter of 2.5-4.5 $\mu \mathrm{m}$ exhibited cohension/adheshion in part.

Overall, the mixed particles on the apical surface circulated concentrically by the interaction of ciliary activity and mucus in the control conditions (Movies 2 and 3 show the movement of particles with diameters of $10-14 \mu \mathrm{m}$ and $2.5-4.5 \mu \mathrm{m}$ under $40 \times$ magnification, respectively). The tracks of the particles also reflected mucociliary transport (Fig. 3A). However, $\mathrm{H}_{2} \mathrm{O}_{2}$ exposure for $24 \mathrm{~h}$ on the apical side significantly inhibited the movement of particles with two different sizes (Movies 4 and 5 show the movement of particles with diameters of $10-14 \mu \mathrm{m}$ and $2.5-4.5 \mu \mathrm{m}$ under $40 \times$ magnification, respectively). The particles left no track for 20 sec (Fig. 3B). It was not clear whether the particle sizes markedly affected the mean migration rate in the control condition, or the decrease in the rate in the $\mathrm{H}_{2} \mathrm{O}_{2}$-exposed condition (Table 1). 


\section{Discussion}

Human airway epithelial cells (Mucil Air ${ }^{\mathrm{TM}}$ ) in ALI culture system were confirmed as fully differentiated epithelial cells by HE and PAS staining. We examined mucociliary transport using fluorescent particles with different sizes on the polarized airway epithelial cells in ALI culture. We also investigated the effects of $\mathrm{H}_{2} \mathrm{O}_{2}$ exposure on mucociliary transport. It was possible to evaluate mucociliary transport by measuring the tracks of the fluorescent particles. Moreover, mucociliary transport was inhibited by $\mathrm{H}_{2} \mathrm{O}_{2}$ exposure.

Airway epithelial cells are composed of a variety of cell types including ciliated, goblet, and basal cells, and their cell population was identified in the MucilAir ${ }^{\mathrm{TM}}$. Ciliated and goblet cells were found on the surface of the epithelial cells (Figs. 2A, B). Mucociliary transport under no fluorescent particles conditions was confirmed by the movement of cellular debris, which was the result of cooperation with ciliated cells and mucous from goblet cells (Movie 1). In the human body, normal mucociliary transport is highly directional toward the pharynx. However, in circular horizontal culture, previous studies have found that the mucus motion is in a rotational, hurricane-like, pattern (Matsui et al. 1998; Oldenburg et al. 2012). The results of the present study were consistent with these reports. Therefore, this cellular model was used as fully differentiated human airway epithelial cells.

There are some assessment techniques for mucociliary transport using ciliary beat 
frequency (CBF) quantified by video record, radioactive tracer and fluorescent particles (Perdersen et al. 1990; Sears et al. 2011; Kunimoto et al. 2012). On the basis of these techniques, previous experimental reports have indicated that environmental pollutants including cigarette smoke, sulphur dioxide, nitrogen dioxide, ozone, diesel exhaust particles, and formaldehyde decrease ciliary activity (Hastie et al. 1990; Knorst et al. 1994; Helleday et al. 1995; Bayram et al. 1998 a, b; Gosepath et al. 2000; Simet et al. 2010). It has also been shown that $\mathrm{H}_{2} \mathrm{O}_{2}$ causes decline in ciliary activity in rats and sheep (Burman and Martin, 1986; Kobayashi et al. 1992). Scanning electron microscopy has revealed that the ciliated cells are severely damaged and epithelial basal cells are poorly connected in guinea-pigs exposed to $\mathrm{H}_{2} \mathrm{O}_{2}$ (Greiff et al. 1999). In the present study, we successfully applied a method to track fluorescent particles for the evaluation of mucociliary transport using polarized human airway epithelial cells, and our observations confirmed that $\mathrm{H}_{2} \mathrm{O}_{2}$ decreased the movement of particles on the cells, which may follow the inhibition of ciliary activity or mucous movement. Accordingly, the present results show that these tools, that is, polarized human airway epithelial cells and fluorescent particles under fluorescent detection, are very useful and easy to apply for evaluations of mucociliary transport and respiratory physiology, because Mucil Air ${ }^{\mathrm{TM}}$ is commercially available and a method to track fluorescent particles is non-radioactive assay. Moreover, the present results are consistent with those of previous studies and support that ROS such as $\mathrm{H}_{2} \mathrm{O}_{2}$ in the ambient atmosphere affects mucociliary transport. 
Other studies have found that exposure to cigarette smoke and ozone increases or does not change mucociliary transport (Gerrity et al. 1993; Zhou et al. 2009). Environmental pollutants may thus have different effects on mucociliary transport depending on the conditions. Alterations of mucociliary transport may be determined by various factors such as species, types of cells and xenobiotics, the number of ciliated cells, the morphology of cilia, the ciliary beating pattern, the quantity and viscoelastic properties of mucus, and experimental conditions such as the exposed concentration and its duration. Accordingly, investigations that focus on each factor may be needed to identify the mechanisms by which mucociliary transport is inhibited by exposure to environmental pollutants.

It has been thought that in nasal breathing, particles with a diameter larger than $10 \mu \mathrm{m}$ are deposited in the oropharynx and nasal cavity, and that those with a diameter smaller than $10 \mu \mathrm{m}$ are deposited in central airways, bronchi and alveoli. However, in mouth breathing, particles with a diameter larger than $10 \mu \mathrm{m}$ can reach bronchi (Heyder et al. 1986; Fernández and Casan 2012). We used fluorescent polystyrene particles with diameters of 10-14 $\mu \mathrm{m}$ and 2.5-4.5 $\mu \mathrm{m}$, which can be deposited in the lower respiratory tract. Using tracheal tubes from the chicken embryos, Henning et al. (2010) have suggested that the clearance rates of varioussized polystyrene particles $(0.05,0.1,1$, and $6 \mu \mathrm{m})$ do not differ, whereas the material properties and the related particle surface chemistry significantly influence mucociliary transport. Snipes et al. (1984) have indicated that particles larger than $7 \mu \mathrm{m}$ are retained after 
deposition in the pulmonary region of the respiratory tract of dogs instilled with a mixture of 3-, 7-, and 13- $\mu \mathrm{m}$ particles. In the present study, polystyrene particles larger than $10 \mu \mathrm{m}$ were tested as large particles, and they were mixed with the same polystyrene particles with 2.5-4.5 $\mu \mathrm{m}$ as small particles. The particle sizes did not affect the movement of particles in the control or the $\mathrm{H}_{2} \mathrm{O}_{2}$ exposure, although polystyrene particles themselves may suppress cellular activities. The difference in particle sizes may not have contributed to the movement of particles in the present experimental conditions or in the circular horizontal culture. Further investigations are needed to understand the effect of differences in particle sizes on mucociliary transport.

\section{Conclusion}

It may be useful to evaluate mucociliary transport by measuring the tracks of fluorescent particles on commercially available polarized human airway epithelial cells using ALI cultures. Exposure of cells to $\mathrm{H}_{2} \mathrm{O}_{2}$ could decrease mucociliary transport. Dysfunction of mucociliary transport induced by oxidative stress and/or environmental pollutants impair airway clearance. Subsequently, inhaled xenobiotics may easily contact with the cells of the respiratory and immune systems such as epithelial and dendritic cells, leading to the induction and/or exacerbation of respiratory diseases. Further investigations with statistical analysis are needed to evaluate mucociliary transport. 


\section{Declaration of interest statement}

The authors report no declarations of interest.

\section{Reference}

Bayram H, Devalia JL, Khair OA, Abdelaziz MM, Sapsford RJ, Sagai M, Davies RJ. (1998a).

Comparison of ciliary activity and inflammatory mediator release from bronchial epithelial cells of nonatopic nonasthmatic subjects and atopic asthmatic patients and the effect of diesel exhaust particles in vitro. J Allergy Clin Immunol, 102, 771-782.

Bayram H, Devalia JL, Sapsford RJ, Ohtoshi T, Miyabara Y, Sagai M, Davies RJ. (1998b).

The effect of diesel exhaust particles on cell function and release of inflammatory mediators from human bronchial epithelial cells in vitro. Am J Respir Cell Mol Biol, 18, 441-448.

Burman WJ, Martin WJ. (1986). Oxidant-mediated ciliary dysfunction. Possible role in airway disease. Chest, 89, 410-413.

Chiba T, Uchi H, Tsuji G, Gondo H, Moroi Y, Furue M. (2011). Arylhydrocarbon receptor (AhR) activation in airway epithelial cells induces MUC5AC via reactive oxygen species (ROS) production. Pulm Pharmacol Ther, 24, 133-140.

Cone AR. (2009). Barrier properties of mucus. Adv Drug Deliv Rev, 61, 75-85.

Dye JA, Adler KB, Richards JH, Dreher KL. (1999). Role of soluble metals in oil fly ash- 
induced airway epithelial injury and cytokine gene expression. Am J Physiol, 277, L498510.

Fernández Tena A, Casan Clarà P. (2012). Deposition of inhaled particles in the lungs. Arch Bronconeumol, 48, 240-246.

Gerrity TR, Bennett WD, Kehrl H, DeWitt PJ, (1993). Mucociliary clearance of inhaled particles measured at $2 \mathrm{~h}$ after ozone exposure in humans. J Appl Physiol, 74, 2984-2989.

Gosepath J, Schaefer D, Brommer C, Klimek L, Amedee RG, Mann WJ. (2000). Subacute effects of ozone exposure on cultivated human respiratory mucosa. Am J Rhinol, 14, 411418.

Greiff L, Erjefält I, Erjefält JS, Wollmer P, Persson CG. (1999). Effects of hydrogen peroxide on the guinea-pig tracheobronchial mucosa in vivo. Acta Physiol Scand, 165, 415-420.

Hastie AT, Patrick H, Fish JE. (1990). Inhibition and recovery of mammalian respiratory ciliary function after formaldehyde exposure. Toxicol Appl Pharmacol, 102, 282-291.

Helleday R, Huberman D, Blomberg A, Stjernberg N, Sandström T. (1995). Nitrogen dioxide exposure impairs the frequency of the mucociliary activity in healthy subjects. Eur Respir J, 8, 1664-1668.

Henning A, Schneider M, Nafee N, Muijs L, Rytting E, Wang X, Kissel T, Grafahrend D, Klee D, Lehr CM. (2010). Influence of particle size and material properties on mucociliary clearance from the airways. J Aerosol Med Pulm Drug Deliv, 23, 233-241. 
Heyder J, Gebhart J, Rudolf G, Schiller CF, Stahlhofen W. (1986). Deposition of particles in the human respiratory tract in the size range $0.005-15 \mu \mathrm{m}$. J Aerosol Sci, 17, 811-825.

Huang S, Caulfuty M. (2009). A novel in vitro cell model of the human airway epithelium. 3R-Info-Bulletin No. 41.

Huang S, Wiszniewski L, Constant S. (2009). In vitro organ culture models of asthma. Drug Discov Today Dis Models, 6, 137-144.

Kim YH, Kim KS, Kwak NJ, Lee KH, Kweon SA, Lim Y. (2003). Cytotoxicity of yellow sand in lung epithelial cells. J Biosci, 28, 77-81.

Knorst MM, Kienast K, Riechelmann H, Müller-Quernheim J, Ferlinz R. (1994). Effect of sulfur dioxide on mucociliary activity and ciliary beat frequency in guinea pig trachea. Int Arch Occup Environ Health, 65, 325-328.

Kobayashi K, Salathé M, Pratt MM, Cartagena NJ, Soloni F, Seybold ZV, Wanner A. (1992). Mechanism of hydrogen peroxide-induced inhibition of sheep airway cilia. Am J Respir Cell Mol Biol, 6, 667-673.

Kunimoto K, Yamazaki Y, Nishida T, Shinohara K, Ishikawa H, Hasegawa T, Okanoue T, Hamada H, Noda T, Tamura A, Tsukita S, Tsukita S. (2012). Coordinated ciliary beating requires Odf2-mediated polarization of basal bodies via basal feet. Cell, 148, 189-200.

Lee M, Heikes BG, O'Sullivan DW. (2000). Hydrogen peroxide and organic hydroperoxide in the troposphere: a review. Atmos Environ, 34, 3475-3494. 
Marano F, Boland S, Bonvallot V, Baulig A, Baeza-Squiban A. (2002). Human airway epithelial cells in culture for studying the molecular mechanisms of the inflammatory response triggered by diesel exhaust particles. Cell Biol Toxicol, 18, 315-320.

Matsui H, Randell SH, Peretti SW, Davis CW, Boucher RC. (1998). Coordinated clearance of periciliary liquid and mucus from airway surfaces. J Clin Invest, 102, 1125-1131.

McDonald RJ, Pan LC, St George JA, Hyde DM, Ducore JM. (1993). Hydrogen peroxide induces DNA single strand breaks in respiratory epithelial cells. Inflammation, 17, 715722.

Oldenburg AL, Chhetri RK, Hill DB, Button B. (2012). Monitoring airway mucus flow and ciliary activity with optical coherence tomography. Biomed Opt Express, 3, 1978-1992.

Pedersen M. (1990). Ciliary activity and pollution. Lung, 168, Suppl 368-776.

Rogers DF. (2007). Physiology of airway mucus secretion and pathophysiology of hypersecretion. Respir Care, 52, 1134-1149.

Ryter SW, Kim HP, Hoetzel A, Park JW, Nakahira K, Wang X, Choi AM. (2007). Mechanisms of cell death in oxidative stress. Antioxid Redox Signal, 9, 49-89.

Seagrave J, Dunaway S, McDonald JD, Mauderly JL, Hayden P, Stidley C. (2007). Responses of differentiated primary human lung epithelial cells to exposure to diesel exhaust at an air-liquid interface. Exp Lung Res, 33, 27-51.

Sears PR, Davis CW, Chua M, Sheehan JK. (2011). Mucociliary interactions and mucus 
dynamics in ciliated human bronchial epithelial cell cultures. Am J Physiol Lung Cell Mol Physiol, 301, L181-186.

Simet SM, Sisson JH, Pavlik JA, Devasure JM, Boyer C, Liu X, Kawasaki S, Sharp JG, Rennard SI, Wyatt TA. (2010). Long-term cigarette smoke exposure in a mouse model of ciliated epithelial cell function. Am J Respir Cell Mol Biol, 43, 635-640.

Smith DJ, Gaffney EA, Blake JR. (2008). Modelling mucociliary clearance. Respir Physiol Neurobiol, 163, 178-188.

Snipes MB, Chavez GT, Muggenburg BA. (1984). Disposition of 3-, 7-, and 13- $\mu \mathrm{m}$ microspheres instilled into lungs of dogs. Environ Res, 33, 333-342.

Stewart CE, Torr EE, Mohd Jamili NH, Bosquillon C, Sayers I. (2012). Evaluation of differentiated human bronchial epithelial cell culture systems for asthma research. J Allergy (Cairo), 943982, doi: 10.1155/2012/943982.

Takeyama K, Dabbagh K, Jeong Shim J, Dao-Pick T, Ueki IF, Nadel JA. (2000). Oxidative stress causes mucin synthesis via transactivation of epidermal growth factor receptor: role of neutrophils. J Immunol, 164, 1546-1552.

Tam A, Wadsworth S, Dorscheid D, Man SF, Sin DD. (2011). The airway epithelium: more than just a structural barrier. Ther Adv Respir Dis, 5, 255-273.

Zhou H, Wang X, Brighton L, Hazucha M, Jaspers I, Carson JL. (2009). Increased nasal epithelial ciliary beat frequency associated with lifestyle tobacco smoke exposure. Inhal 
Toxicol, 21, 875-881. 
Figure legends

Fig. 1. The position for the observation of fluorescent particles on airway epithelial cells cultured in an air-liquid interface (ALI) system.

Fig. 2. Morphological features of polarized human airway epithelial cells. (A) The structure of airway epithelial cells was indicated by hematoxylin and eosin staining (B) Mucous localization was shown by periodic acid-Schiff staining. Magnification: $\times 400$.

Fig. 3. Analysis of mucociliary transport for 20 sec after exposure to $\mathrm{H}_{2} \mathrm{O}_{2}$ for $24 \mathrm{~h}$ on the apical surface, which was measured by tracking fluorescent particles with diameters of 10-14 $\mu \mathrm{m}$ and $2.5-4.5 \mu \mathrm{m}$. The images of tracking fluorescent particles were shown in (A) saline solution ( $0.9 \% \mathrm{NaCl}, 1.25 \mathrm{mM} \mathrm{CaCl} 2,10 \mathrm{mM}$ HEPES) exposure as control. (B) $\mathrm{H}_{2} \mathrm{O}_{2}$ exposure. Magnification: $\times 200$. 


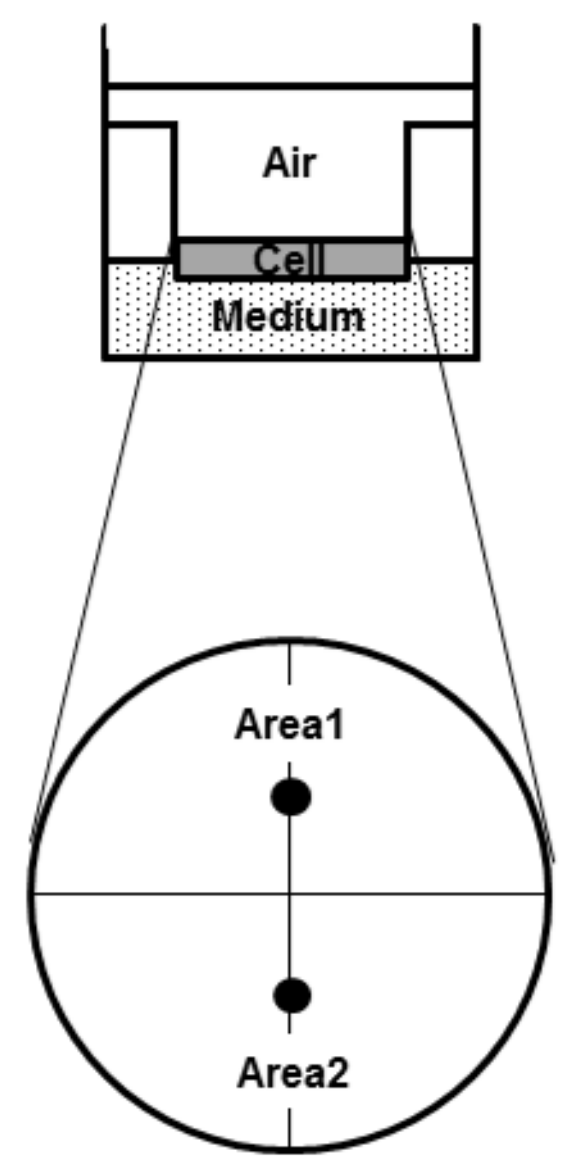

Fig. 1 
A

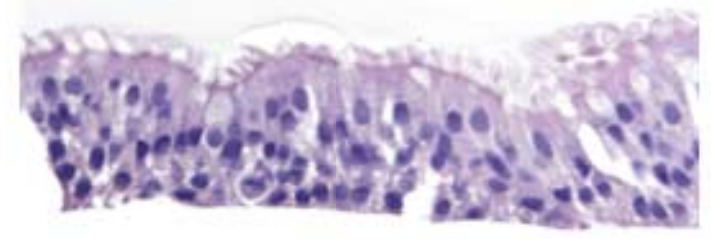

B

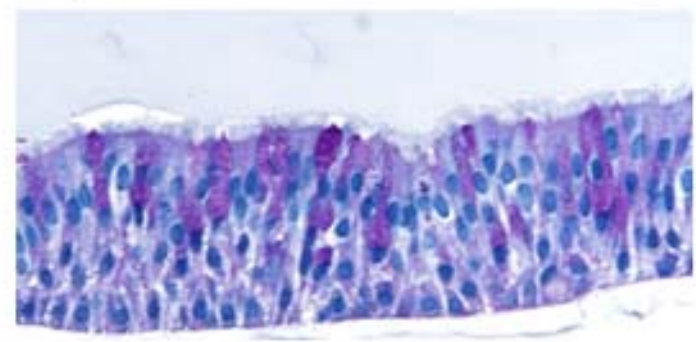

Fig. 2 
A

Time

10-14 $\mu \mathrm{m}$

(Area 1)

$0 \mathrm{~s}$

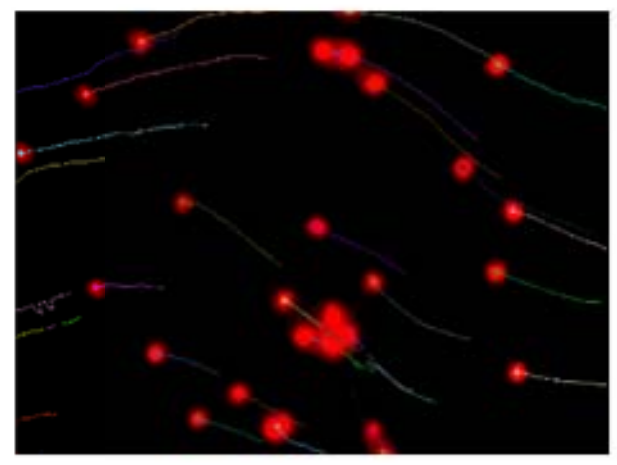

10-14 $\mu \mathrm{m}$

(Area 2)

2.5-4.5 $\mu \mathrm{m}$ (Area 1)
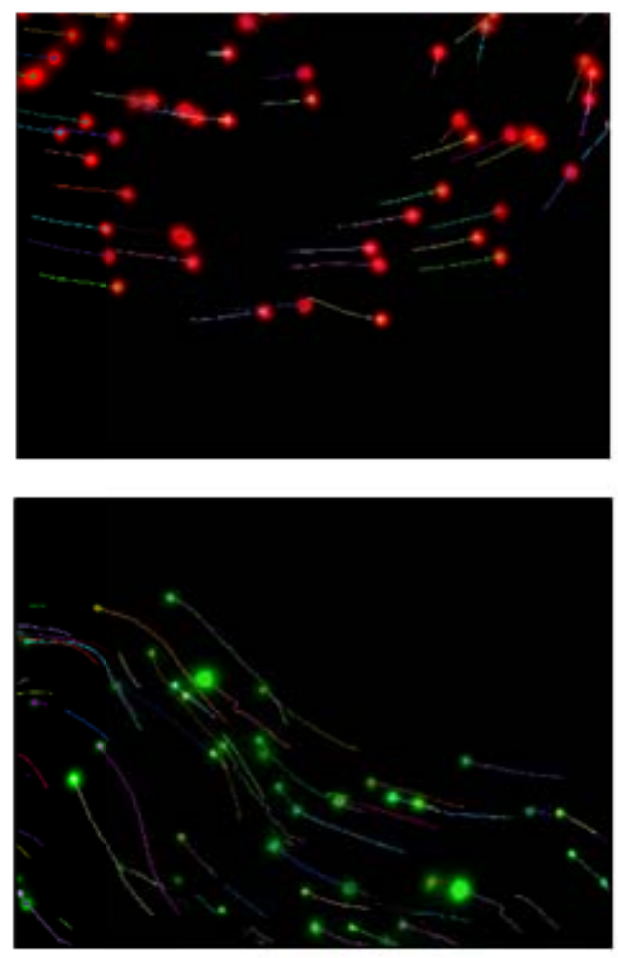

2.5-4.5 $\mu \mathrm{m}$ (Area 2)
$20 \mathrm{~s}$
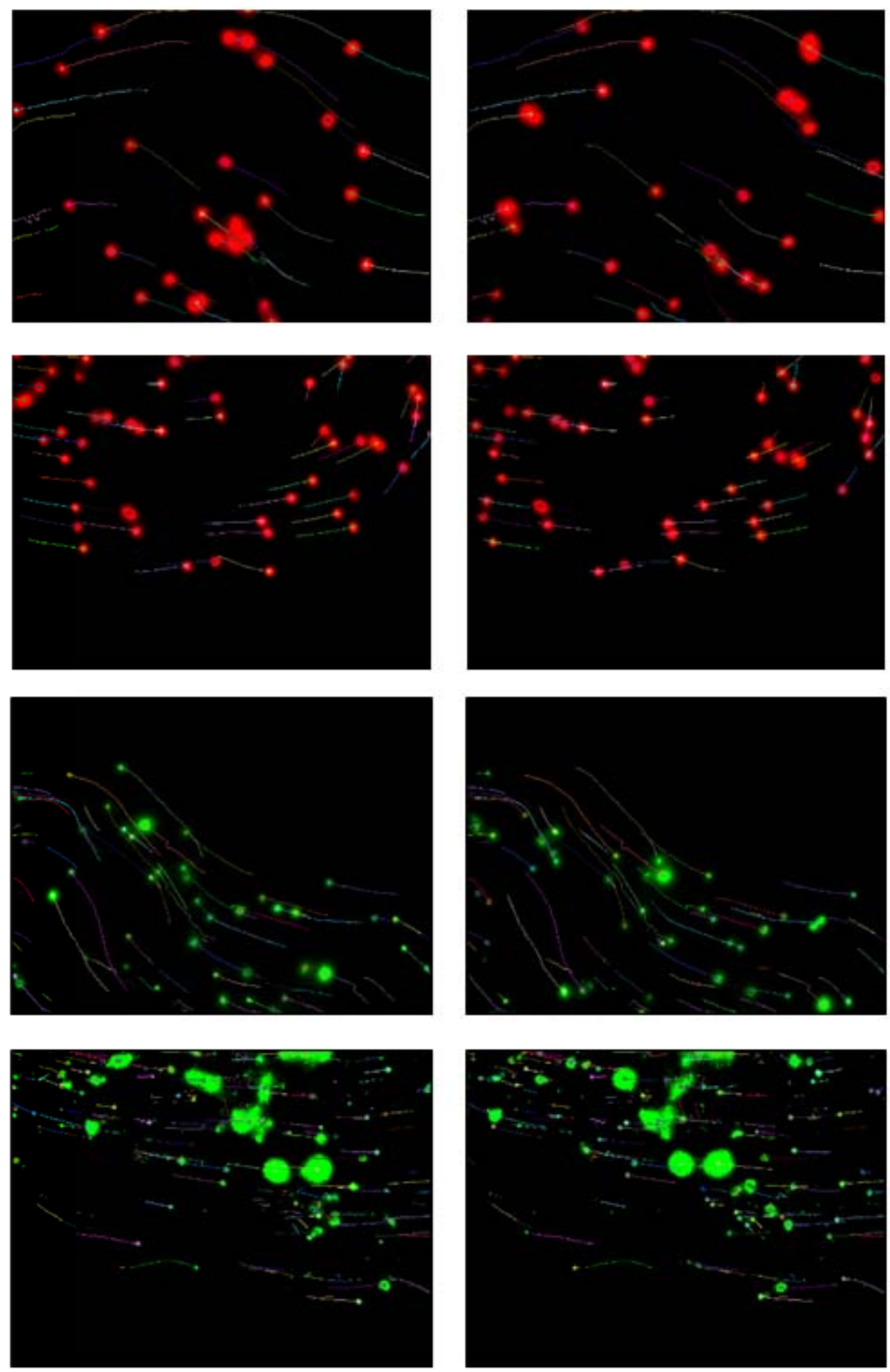

Fig. 3(A) 
Time
$0 \mathrm{~s}$
$20 \mathrm{~s}$

10-14 $\mu \mathrm{m}$

(Area 1)
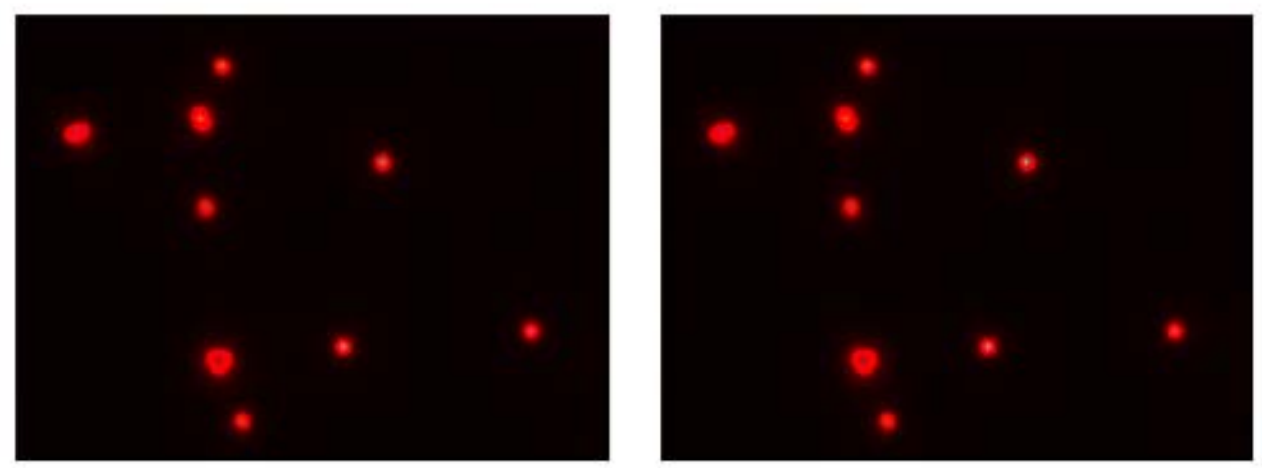

10-14 $\mu \mathrm{m}$

(Area 2)
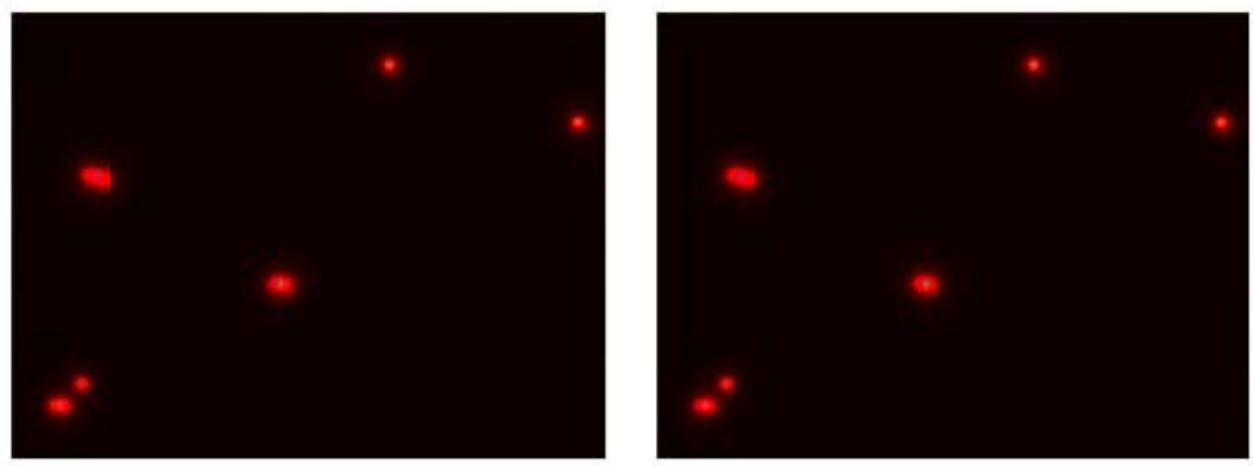

2.5-4.5 $\mu \mathrm{m}$

(Area 1)
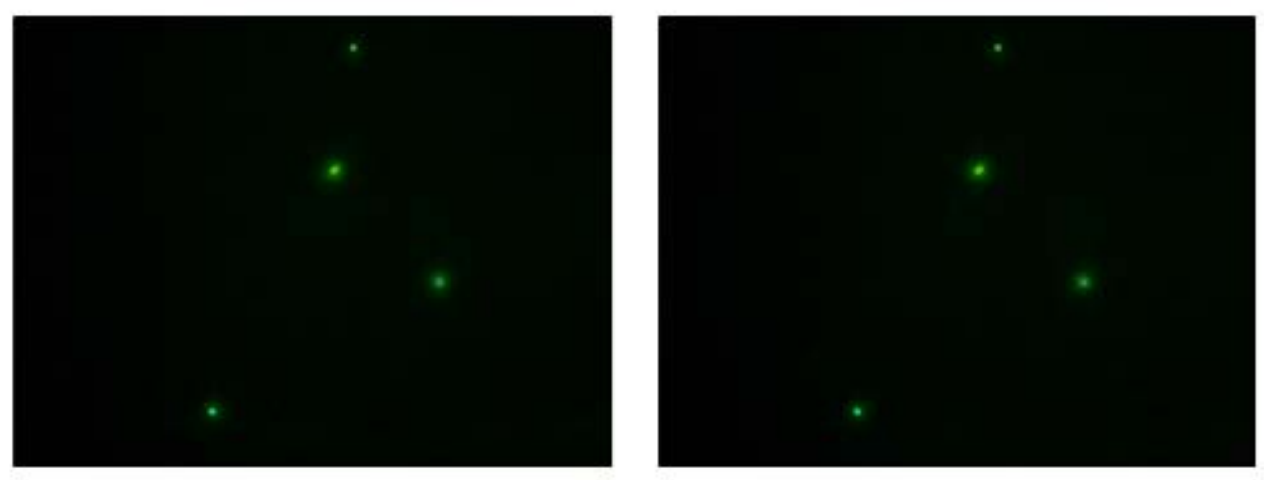

2.5-4.5 $\mu \mathrm{m}$ (Area 2)
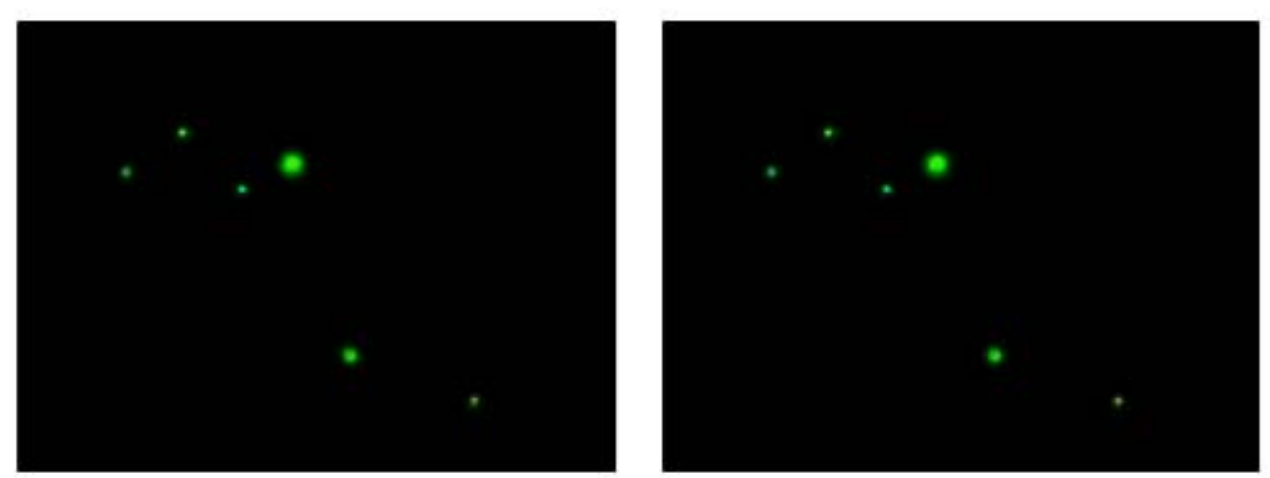

Fig. 3(B) 